\title{
GRPR Gene
}

National Cancer Institute

\section{Source}

National Cancer Institute. GRPR Gene. NCI Thesaurus. Code C95065.

This gene plays a role in the regulation of both signal transduction and cell proliferation. 